\title{
Development of an attitude scale towards story writing for third- fourth-grade primary school students
}

\author{
Bengisu Kaya \\ Zonguldak Bülent Ecevit University, Zonguldak, Turkey, bengisu.kaya@beun.edu.tr \\ ORCID: 0000-0001-6299-1370 \\ Adnan Kan \\ Gazi University, Ankara, Turkey, adnankan@gazi.edu.tr \\ ORCID: 0000-0002-3610-0033
}

\begin{abstract}
The aim of this study is to develop a valid and reliable Likert-type attitude scale for toward story writing for third- and fourth-grade primary school students. 354 children from three different schools in the Ereğli district of Zonguldak province, Turkey constituted the sample of this research. Exploratory factor analysis (EFA) and confirmatory factor analysis (CFA) were carried out to analyze the data. EFA identified 20 items and two factors for the scale. These factors were termed as "positive attitude" and "negative attitude." CFA confirmed the two-factor structure of the scale. The Cronbach's alpha coefficients were found to be .92 for the overall scale, .90 for the first factor, and .89 for the second factor. The test-retest reliability coefficients were .82 for the overall scale, .87 for the first factor, and .83 for the second factor. The results indicate a valid and reliable measure for students' attitudes towards story writing.

Keywords: Story writing, Attitude, Scale development, Validity-Reliability, Third-and fourth-grade primary school students
\end{abstract}

\section{İlkokul üçüncü-dördüncü sınıf öğrencileri için hikâye yazmaya yönelik tutum ölçeği geliştirilmesi}

ÖZ Bu çalışmanın amacı, ilkokul üçüncü ve dördüncü sınıf öğrencilerinin hikâye yazmaya yönelik tutumlarının belirlenmesi için geçerli ve güvenilir bir tutum ölçeği geliştirmektir. Araştırmanın çalışma grubunu Zonguldak ili Ereğli ilçesinde üç farklı ilkokulda üçüncü ve dördüncü sınıfta öğrenim gören toplam 354 öğrenci oluşturmaktadır. Veriler üzerinde Açımlayıcı Faktör Analizi (AFA) ve Doğrulayıcı Faktör Analizi (DFA) yapılmıştır. AFA sonucunda ölçeğin 20 maddeden ve iki faktörden oluştuğu belirlenmiştir. Bu boyutlar "olumlu tutum" ve "olumsuz tutum" olarak adlandırılmıştır. DFA analizi sonucunda iki faktörlü yapı doğrulanmıştır. Ölçeğin tamamı için Cronbach Alfa güvenirlik katsayısı .92 iken birinci alt faktöre ilişkin $\alpha .90$, ikinci alt faktöre ilişkin $\alpha .89$ olarak bulunmuştur. Ölçeğin tümüne ait test tekrar test güvenirliği $.82 \mathrm{iken,} \mathrm{birinci} \mathrm{alt} \mathrm{faktöre} \mathrm{ilişkin} \mathrm{test} \mathrm{tekrar}$ test güvenirliği .87 , ikinci alt faktöre ilişkin test tekrar test güvenirliği ise .83 olarak hesaplanmıştır. Bulgular sonucunda, ölçekle hikâye yazmaya yönelik tutumun geçerli ve güvenilir bir şekilde ölçülebileceği ortaya konmuştur.

Anahtar Hikâye yazma, Tutum, Ölçek geliştirme, Geçerlik-Güvenirlik, Illkokul üçüncü ve dördüncü Kelimeler: sinı ögrencileri 


\section{INTRODUCTION}

Affective variables such as attitude, self-efficacy, and anxiety affect many other factors in students' willingness and interest in a course (Kan \& Akbaş, 2005). According to Tompkins (2006) affective variables such as attitude and motivation have a significant role in literacy education. It is stated that the attitudes which affect writing skills may also affect story writing skills as well. At this point, it may be helpful to explain the concept of attitude before talking about writing skills and attitudes towards story writing.

There are many different definitions of "attitude" in the literature. Attitude, according to Thurstone, is the degree of negative or positive affect related to the psychological object (Edwards, 1957). According to Cohen and Swerdlik (2015), in formal terms, attitude is a tendency which is most likely learned, used to react in a characteristic way to a certain stimulus. Another definition of attitude is "a learned tendency towards continuously giving a positive or negative response regarding a certain object" (Fishbein \& Ajzen, as cited in Graham, Berninger, \& Fan, 2007, p. 518; Williams, 2012, p. 15). Traditionally, attitudes are conceptualized as either negative or positive along the unit of endpoints (Graham et al., 2007; Kear, Coffman, McKenna, \& Ambrosio, 2000; Knudson, 1991). For this reason, it can be stated that when an individual relates a psychological object to a positive situation, s/he develops a positive attitude towards it; similarly, an individual who relates a negative situation with the same psychological object develops a negative attitude towards it (Edwards, 1957). According to McKenna et al., there are three concepts involved in the formation of attitude: the individual's beliefs about an object, behavioral intentions regarding that object, and experiences about the object (cited in Williams, 2012).

Every individual has different interest, willingness, and attitude regarding writing skills, which is an aspect important in individuals' social life and communication (Göçer, 2014a). As explained in Elementary Turkish Curriculum and Guide for grades 1-5 (Republic of Turkey Ministry of National Education Board of Education and Discipline, 2009) Akyol (2013) describes different types of writing, such as narrative, descriptive, and persuasive, described for the motoric production of symbols, and signs necessary to express our thoughts. Expressions of feelings, thoughts, desires, designs in writing is a multidimensional skill and requires a desire to write, which is why writing is a process that involves hard work and practice for many years (Susar-Kırmızı, 2009).

While writing is an essential part of some people's life (Göçer, 2014b), for the others it is an activity which is engaged in only when necessary. Tompkins (1982, p. 718) explains a similar situation for story writing: "Some children write a story since they want it, and some children do it because they have to." The emotions and thoughts that emerged in positive and negative ways against writing by individuals reflect their attitudes towards writing.

Graham et al. (2007) described the act of writing in relation to writing attitude as an emotional manner which includes the way the writers' feelings change from happiness and sadness. In line with this definition, it can be stated that story-writing attitude is an emotional state relating to how story-writing behavior is affected by whether students enjoy the story-writing process.

John Daly's work since 1975 has contributed greatly to research on writing attitude (Krawczyk, 2005). According to Daly (1985), positive attitude towards writing depends on the improvement of writing skills, and continuity in writing. Students' writing attitudes are mostly measured on Likert-type scales (Graham et al., 2007; Kear et al., 2000; Knudson, 1991). The Bogardus, Thurstone, and Guttman's scale is also among the most widely used scales (Turan-Oluk, Kan, \& Ekmekçi, 2016).

When the writing attitude scale is used after students have completed their writing tasks, at home or at school, their desires and feelings are measured retrospectively, including their happiness or sadness at 
different times (Graham et al., 2007). Based on these views in the literature, it can be said that it is important to determine -as a form of writing- the story-writing attitudes of students and that Likert-type scales can be used to measure this attitude.

Individuals use their writing skills throughout their lives for a variety of reasons, such as expressing themselves, conveying feelings and thoughts. For this reason, it is important to conduct research to determine the attitudes of students in relation to this skill in order to acquire and effectively use writing skills. However, since the pre-school period, students are familiar with the structures of narrative texts (Ateş, 2011), and in primary school, writing studies are usually focused on story texts, so the existing body of research indicates the need for research on story text. While many studies have developed instruments to measure attitudes towards writing (Clark \& Dugdale, 2009; Graham et al., 2007; Kear et al., 2000; Knudson, 1991; Knudson, 1992; Susar-Kırmızı, 2009; Temizkan \& Sallabaş, 2009); any research determining the attitudes towards story writing which is a type of writing has not been observed. In Gallick-Jackson's (1997) study on story writing, students' attitude towards writing was determined using a writing attitude instrument. However, students' attitudes towards story writing may differ from their attitudes towards writing. For this reason, the aim of this study is to develop a valid and reliable Likert-type attitude scale for toward story writing for third- and fourth-grade primary school students and to contribute to the elimination of deficiencies seen in the field by examining the writing attitude of primary school students. The validity and reliability of a Likert-type scale which was developed to measure the story-writing attitudes of third- and fourth-grade primary school students. With this purpose in mind, a review of the literature was carried out first to identify relevant definitions of attitude. The items of the proposed scale were prepared based on the definitions of attitude in the literature. The definitions on which the items were based are given in the "Scale Development" section.

The Elementary Turkish Curriculum and Guide (Grades 1-5) (Republic of Turkey Ministry of National Education Board of Education and Discipline, 2009) shows that story writing is taught from the first grade. The Turkish (Grades 1st-8th) Curriculum (Republic of Turkey Ministry of National Education Board of Education and Discipline, 2015) set the story writing objectives "students are able to write about a certain event following the sequence of events" for second-year students and "students are able to express their feelings and thoughts by means of writing" for third-year students. Starting in the fourth year, objectives regarding narrative writing were included. It is very important to determine students' attitudes towards story writing, and chancing negative into positive attitudes in order to achieve the objectives of the curriculum.

It is stated that there is clearly a need for more research in this field because the literature lacks research on attitudes towards story writing. The scale developed here to measure attitudes towards story writing skills among students in the first years of primary school is the first of its kind, making this study an important contribution.

\section{METHODOLOGY}

\section{Participants}

Factor analyzes researches the sample should be at least five or ten times bigger than the number of items in the scale was considered in determining the number of the participants (Tavşancil, 2010). According to Tabachnick and Fidell (1996, p. 640) "it is comforting to have at least 300 cases for factor analysis". With this aim the participants of this study were 354 third- and fourth-grade students from three different schools of high, middle, and low socioeconomic status (SES) in the Ereğli district of Zonguldak province, Turkey by considering the item numbers (30) in the first draft of this scale. Table 1 describes of the number and percentage of the participants' gender and SES. 
Table 1

Participants of The Research

\begin{tabular}{lrrr}
\hline Student & \multicolumn{1}{c}{ Female } & \multicolumn{1}{c}{ Male } & Total \\
SES* & & & \\
\hline High SES & $48(13.6 \%)$ & $65(18.4 \%)$ & 113 \\
Mid SES & $53(15 \%)$ & $59(16.6 \%)$ & 112 \\
Low SES & $64(18 \%)$ & $65(18.4 \%)$ & 129 \\
\hline Total & $165(46.6 \%)$ & $189(53.4 \%)$ & 354
\end{tabular}

*Socioeconomic status (SES) of schools was determined by taking into consideration the characteristics of the school environment and the opinions of the school administrators.

Exploratory factor analysis (EFA) and confirmatory factor analysis (CFA) were carried out on the data obtained from 354 students. Additional data were obtained from 12 students from each school, 36 in total, for the test-retest reliability (TRR) analysis. The participants undertook story writing practices in their classrooms in line with the curriculum.

\section{Development of the Attitude Scale Towards Story Writing}

In the first phase of the scale development, the relevant scales among the literature were reviewed and researched whether related scales were existed. This review concluded that the literature lacks research on attitudes towards story writing.

The attitude variable contain three dimensions such as cognitive, affective, and behavioral (Tavşanc1l, 2010). For this reason, the items were written considering the cognitive, affective, and behavioral dimensions of story writing. In addition, scales produced by other researchers on writing were reviewed and benefited the item-writing phase.

Thirty items were written to measure third- and fourth-grade primary school students' attitudes towards story writing. Three field experts, one assessment and evaluation expert, and a Turkish language expert were consulted on the appropriateness of the items and the language used. An explanation of the aim of the scale was included and a draft scale was developed. Sixteen positive and 14 negative items rated on a five-point Likert-type scale - ranging from (1) "strongly disagree" to (5) "strongly agree" - were included in the draft scale. Prior to the factor analysis, the scores of the negative items were reversed. Categories, indicators, and descriptions of attitudes towards story writing and the items relevant to each description are presented in Table 2.

Table 2

Categories, Indicators, and Descriptions of Attitudes towards Story Writing, and Items Written for Each Description

\begin{tabular}{|c|c|c|c|c|}
\hline Category & Indicator & Description & Source & $\begin{array}{l}\text { Items with } \\
\text { regard to the } \\
\text { description }\end{array}$ \\
\hline \multirow[t]{2}{*}{$\begin{array}{l}\text { POSITIVE } \\
\text { ATTITUDE }\end{array}$} & $\begin{array}{l}\text { Like writing } \\
\text { stories }\end{array}$ & $\begin{array}{l}\text { Participating happily in writing } \\
\text { activities, explaining thinking, } \\
\text { having fun, making it a lifestyle, } \\
\text { writing more often, enjoying the } \\
\text { writing process and the product }\end{array}$ & $\begin{array}{l}\text { Daly, cited in Krawczyk (2005), } \\
\text { Göçer (2014b), McKenna, } \\
\text { Kear and Ellsworth, cited in } \\
\text { Zumbrunn (2010), Tompkins } \\
(1982)\end{array}$ & $\begin{array}{l}\mathrm{I} 2, \mathrm{I} 4, \mathrm{I} 14, \mathrm{I} 16, \\
\mathrm{I} 18, \mathrm{I} 19, \mathrm{I} 22, \mathrm{I} 24\end{array}$ \\
\hline & $\begin{array}{l}\text { Self- } \\
\text { development }\end{array}$ & $\begin{array}{l}\text { Being more diligent, setting } \\
\text { goals }\end{array}$ & $\begin{array}{l}\text { Bandura (1995), } \\
\text { Graham, cited in Williams (2012) }\end{array}$ & I23, I29 \\
\hline \multirow{2}{*}{$\begin{array}{l}\text { NEGATIVE } \\
\text { ATTITUDE }\end{array}$} & $\begin{array}{l}\text { Avoiding } \\
\text { writing } \\
\text { stories }\end{array}$ & $\begin{array}{l}\text { Resisting and avoiding writing } \\
\text { activities, reduced efficiency in } \\
\text { the writing process }\end{array}$ & $\begin{array}{l}\text { Daly as cited in Krawczyk (2005), } \\
\text { Graham et al. (2007) }\end{array}$ & $\begin{array}{l}\mathrm{I} 5, \mathrm{I} 8, \mathrm{I} 9, \mathrm{I} 10, \\
\mathrm{I} 25, \mathrm{I} 27\end{array}$ \\
\hline & $\begin{array}{l}\text { Dislike } \\
\text { writing } \\
\text { stories }\end{array}$ & $\begin{array}{l}\text { Making less effort, physical or } \\
\text { emotional show of anxiety, } \\
\text { sadness, and anger }\end{array}$ & $\begin{array}{l}\text { Graham et al. (2007), Krawczyk } \\
\text { (2005) }\end{array}$ & $\mathrm{I} 15, \mathrm{I} 17, \mathrm{I} 20, \mathrm{I} 21$ \\
\hline
\end{tabular}

This table was reorganized following EFA and items $6,7,11,12,13,26,28$, and 30 were excluded from the scale, and so are not included here. 


\section{Data Collection}

By considering ethical issues, in the data collection stage, the potential participants were informed about the aim of the study and those who were willing to participate were determined. The participants were told that they did not have to give their name and were assured that their identities would not be revealed. After explaining the subject of the scale, the researchers asked the participants to fill the scale. The researcher personally collected the data and the cases where students' attention might be distracted and the answering might be prevented were particularly avoided. The students needed 20-25 minutes to complete the scale. The data collection process took approximately one month with the test-retest.

\section{Data Analysis}

Various analyses were conducted to obtain evidence of the reliability and validity of the Attitude towards Story Writing Scale. In order to determine the construct validity of the scale, firstly, EFA and then DFA was carried out on the resulting structure.

SPSS 21.0 software was used for EFA, which revealed which factors the items in the scale belong to. At this stage, the Kaiser Meyer Olkin test (KMO) and Bartlett's Sphericity test (BST) were carried out to investigate the appropriateness of the data in the principal component analysis. To identify the factors, varimax rotation was used. Cronbach's alpha $(\alpha)$ coefficients were calculated for the overall scale and for each factor separately.

Lisrel 8.8 software was used for CFA to check the appropriateness of the model revealed by EFA. Chisquared $\left(\chi^{2}\right)$, degree of freedom (DF), adjusted goodness of fit index (AGFI), goodness of fit index (GFI), normed fit index (NFI), non-normed fit index (NNFI), incremental fit index (IFI), comparative fit index (CFI) and root-mean-square error of approximation (RMSEA) values were considered to evaluate model appropriateness.

$\alpha$ coefficients were calculated for the overall attitude scale and individual factors to check the internal consistency of the scale. TRR was also calculated to indicate the reliability of the scale. Tavşancil (2010) notes that an interval of two-three or four-six weeks is sufficient between two measurements. Hence, the scale was applied again to a group of students two weeks after the first application. Because the literature indicates the need at least 30 participants in order to ensure normal distribution (Tavşancil, 2010; Aiken, cited in Gürefe \& Kan, 2013), thirty-six students completed the second exercise.

\section{FINDINGS}

In this section, the reliability and validity issues for the Attitude Scale Towards Story Writing are discussed.

\section{Findings Related to Validity}

Both the content and construct validity of the scale were investigated. The principal component analysis was conducted to check construct validity, to determine the factors on which the items loaded, and to label the factors. 
$\mathrm{KMO}$ and BST were carried out to determine the appropriateness of the data for the analysis. The results revealed a KMO value of .945. Kaiser (1974) indicated that factor analysis can be done when the KMO value is greater than 0.5, while Pallant (2001) suggests a KMO value greater than 0.6 (cited in KiliçÇakmak, Çebi, \& Kan, 2014, p. 758). The KMO value obtained in this study was greater than the values suggested in the literature.

The significance of the Chi-squared statistics obtained at the end of the BST indicated the normal distribution of the data with multiple variables. The BST was found to be significant $\chi^{2}=3408.91$; $p=0.00$ ). In the light of these results, the scale was found to be appropriate for factor analysis.

As a result of the first EFA, the items of the scale were collected under five factors. These five factors explained $56.51 \%$ of the variance of the scale. It was determined that some factors were loaded with very few items, some items were loaded on more than one factor, and some load values were lower than .30. These items were excluded from the scale one by one and EFA was repeated each time. The results indicated a KMO value of .942 . The BST result was also significant $\left(\chi^{2}=4817.85 ; p=0.00\right)$. After the exclusion of inappropriate items with negative conditions, the remaining 20 items were collected under two factors (components). The eigenvalues of these factors are presented in Figure 1.

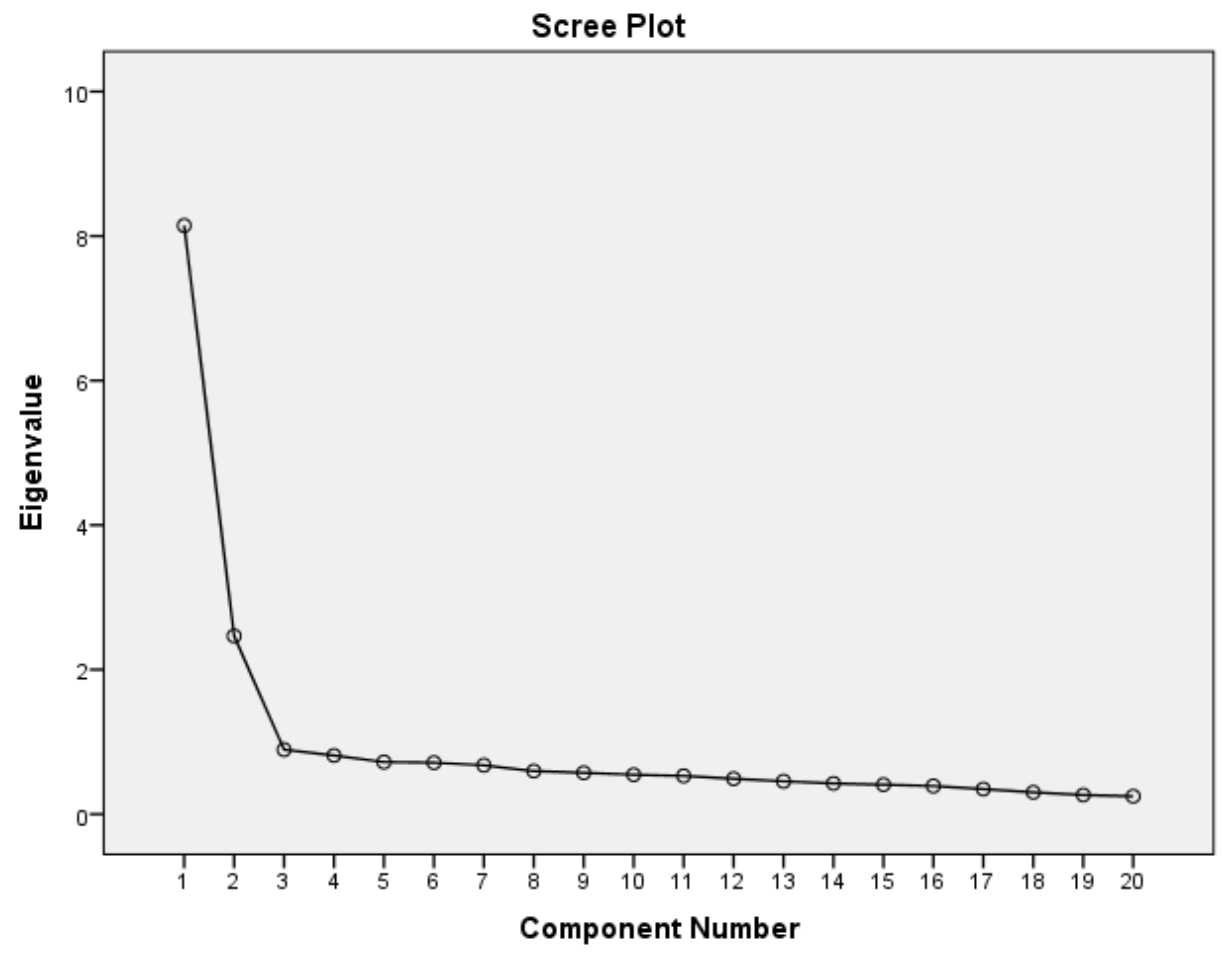

Figure 1. Eigenvalues of scale factors

In order to make the factor loads more distinct in this analysis, varimax, an orthogonal rotation technique, was used. For an item to be loaded on a factor, the factor load should be at least 40 (DeVellis, 2014). For this reason, a value of .40 was considered as the criterion for the factor loads and the items with a factor load lower than .40 were not included in the analysis. Table 3 presents the EFA values of the 20 items kept for analysis. 
Table 3

Factor Loadings and EFA Results for Scale Items

\begin{tabular}{|c|c|c|c|c|}
\hline $\begin{array}{c}\text { Item } \\
\text { No }\end{array}$ & Item & $\begin{array}{c}\text { Factor } \\
1\end{array}$ & $\begin{array}{l}\text { Factor } \\
2\end{array}$ & $\begin{array}{l}\text { Common Factor } \\
\text { Variance }\end{array}$ \\
\hline 18 & I like spending my free time writing stories. & .80 & & .68 \\
\hline 22 & I write a story whenever possible. & .80 & & .65 \\
\hline 16 & Writing stories is my most favorite activity. & .79 & & .68 \\
\hline 24 & I prefer writing stories instead of playing games. & .72 & & .55 \\
\hline 19 & $\begin{array}{l}\text { Besides my homework, I also write stories on my own } \\
\text { whenever I want. }\end{array}$ & .72 & & .54 \\
\hline 14 & I like expressing what I feel/think by writing stories. & .67 & & .52 \\
\hline 2 & $\begin{array}{l}\text { I cannot think of a more enjoyable activity than writing } \\
\text { a story. }\end{array}$ & .66 & & .44 \\
\hline 29 & I do research to develop my story-writing skills. & .59 & & .40 \\
\hline 4 & I have a strong wish to write stories. & .59 & & .40 \\
\hline 23 & $\begin{array}{l}\text { I read books and magazines to develop my story-writing } \\
\text { skills. }\end{array}$ & .55 & & .40 \\
\hline 9 & $\begin{array}{l}\text { I want to escape from the classroom when my teacher } \\
\text { asks me to write a story. }\end{array}$ & & .76 & .59 \\
\hline 10 & I find various excuses not to write stories. & & .75 & .59 \\
\hline 15 & I hate my teacher when s/he asks me to write a story. & & .73 & .53 \\
\hline 25 & I hesitate to write a story. & & .71 & .58 \\
\hline 21 & I do not like writing stories at all. & & .70 & .70 \\
\hline 17 & I feel disturb when I need to write a story. & & .70 & .54 \\
\hline 5 & I think that writing stories is a waste of time. & & .64 & .41 \\
\hline 20 & I feel bored when I am writing stories. & & .64 & .61 \\
\hline 8 & Writing a story is not my favorite activity. & & .61 & .50 \\
\hline \multirow[t]{4}{*}{27} & $\begin{array}{l}\text { I spend too much time on my desk and cannot write } \\
\text { anything. }\end{array}$ & & .50 & .32 \\
\hline & Eigenvalue & 8.15 & 2.27 & - \\
\hline & Variance Explained $(\%)$ & 40.73 & 12.33 & - \\
\hline & Total Variance Explained $(\%)$ & & 53.06 & - \\
\hline
\end{tabular}

In Table 3, the factor load values of EFA are listed from high to low. A close look at the table shows that the first factor consists of ten items whose factor loads range between .55 and .80 and that the second factor consists of ten items whose factor loads range between .50 and .76. All of the factors explained $53.06 \%$ of the total variance. The first factor explained $40.73 \%$ of the total variance and was labeled "Positive Attitude." The second factor explained $12.33 \%$ of the total variance and was labeled "Negative Attitude."

The relationships between the factors of the scale were investigated with the same participant group. The correlation coefficients between the factors are presented in Table 4.

Table 4

Correlation Coefficients

\begin{tabular}{lll}
\hline Dimensions & Positive Attitude & Negative Attitude \\
\hline Positive Attitude & 1.00 & $.38^{*}$ \\
Negative Attitude & & 1.00 \\
\hline
\end{tabular}

$* p<0.05$

As seen in Table 4, the correlation between the two factors was .38 and significant at the .05 level.

CFA was carried out to confirm the model (construct) revealed by the exploratory factor analysis. Factor distributions and load values are given in Figure 2. 


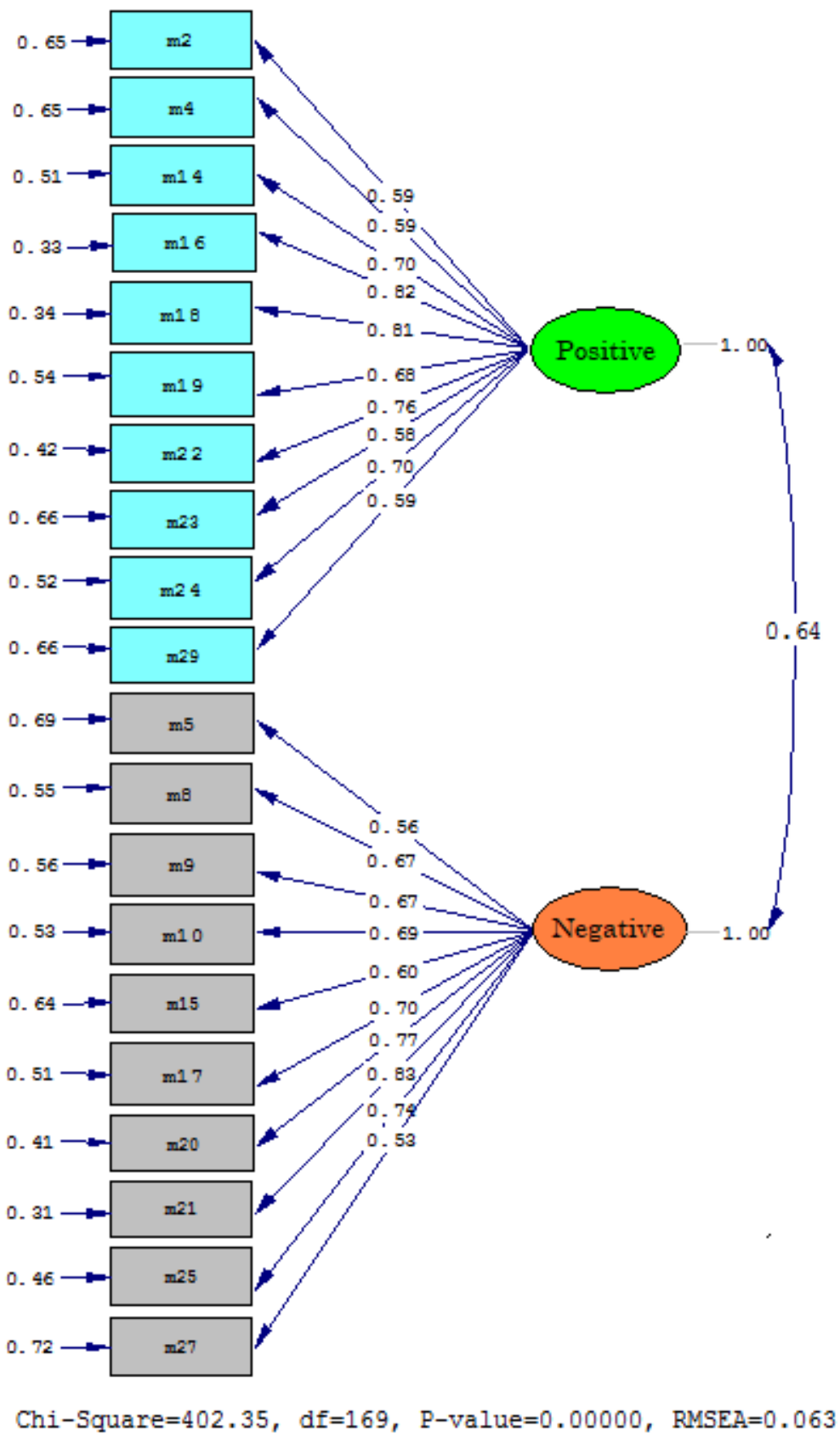

Figure 2. CFA path diagram of the scale

The CFA model shows that the load values of items and factors range between 0.53 and 0.83 . CFA found that $\chi^{2}=402.35, \mathrm{df}=169, p=.00, \mathrm{RMSEA}=.063$, GFI=.90, AGFI=.87, NFI=.96, NNFI=.98, $\mathrm{CFI}=.98$ and $\mathrm{IFI}=.98$. According to the data obtained by CFA, the correlation between the two factors was .64 and significant, which indicates that the factors are related to each other. Considering these values, it can be said that the items in the scale represent the construct of the scale; in other words, the model accords with the results presented by EFA.

\section{Findings Related to Reliability}

In order to determine the reliability of the scale, the correlations between item-total test scores were calculated for each item and the Cro coefficients were calculated for each dimension determined by EFA. The relevant data are presented in Table 5. 
Table 5

Item Total Correlations for Items and Cronbach Alpha Coefficients

\begin{tabular}{lcccc}
\hline $\begin{array}{c}\text { Items and } \\
\text { Factors }\end{array}$ & $X$ & $\mathrm{~S}$ & $\begin{array}{c}\text { Item Total } \\
\text { Correlation }\end{array}$ & $\begin{array}{c}\text { Cronbach's Alpha Coefficient } \\
\text { When the Item was Removed }\end{array}$ \\
\hline \multicolumn{5}{c}{ Factor 1: Positive attitude $(\alpha=.90)$} \\
\hline I2 & 2.9011 & 1.29451 & .56 & .89 \\
I4 & 3.4011 & 1.25844 & .56 & .89 \\
I14 & 3.7881 & 1.23351 & .65 & .89 \\
I16 & 3.4096 & 1.32700 & .76 & .88 \\
I18 & 3.4802 & 1.28883 & .76 & .88 \\
I19 & 3.3757 & 1.37050 & .64 & .89 \\
I22 & 3.2090 & 1.29121 & .72 & .88 \\
I23 & 3.8842 & 1.14433 & .56 & .89 \\
I24 & 3.1751 & 1.32008 & .66 & .89 \\
I29 & 3.6186 & 1.30321 & .57 & .89 \\
\hline \multicolumn{5}{c}{ Factor 2: Negative Attitude $(\alpha=.89)$} \\
I5 & 3.8814 & 1.26291 & .54 & .89 \\
I8 & 3.8136 & 1.22959 & .63 & .88 \\
I9 & 4.3927 & 1.06505 & .65 & .88 \\
I10 & 4.2966 & 1.08799 & .67 & .88 \\
I15 & 4.5056 & 1.02447 & .59 & .88 \\
I17 & 3.9520 & 1.25973 & .66 & .88 \\
I20 & 3.9802 & 1.23093 & .69 & .87 \\
I21 & 4.1271 & 1.12565 & .76 & .88 \\
I25 & 4.0678 & 1.11184 & .69 & .89 \\
I27 & 3.8362 & 1.33433 & .49 &
\end{tabular}

Reliability coefficients of .70 or higher are generally considered sufficient (Nunnally, cited in KiliçÇakmak et al., 2014, p. 9). The $\alpha$ coefficients were found to be .92 for the overall scale, .90 for the first factor, and .89 for the second factor.

Table 5 presents the scale has very high reliability values. This is important because high reliability coefficients indicate that the items in a scale are consistent with each other and that the scale consists of items bearing the same characteristics (Tavşanc1l, 2010). Kline (2011, p. 70) noted that a reliability coefficient of about 0.90 is excellent, 0.80 is very good, and 0.70 is sufficient. .

When the total test correlations of items in each factor were considered, the following results were obtained. The values of item total test correlations for the Positive Attitude factor range between $r=.56$ and $r=.76$. The values of item total test correlations for Negative Attitude factor range between $r=.49$ and $r=.76$. Item total correlations of .30 or higher provide the validity of the scale items (Nunnally \& Bernstein, 1994). Coefficients were higher than .30 for each item in this scale, which indicates that the scale items measure what they are intended to measure.

The scale was applied again to 36 students two weeks after its first application and the TRR of the scale was calculated based upon the data obtained. The TRR was found to be .82 for the overall scale, .87 for the first factor, and .83 for the second factor. These results reveal that the scale scores are consistent (stable) over time. This indicates that the scale obtained is highly reliable.

Table 6

Test-Retest Correlation Coefficients

\begin{tabular}{llcc} 
& Dimensions & Positive Attitude & Negative Attitude \\
\cline { 2 - 4 }$* p<0.01$ & Positive Attitude & 1.00 & $.41^{*}$ \\
Negative Attitude & & 1.00 \\
\hline & & &
\end{tabular}


As shown in Table 6, the correlation between the factors was .41 and significant at the .01 level.

\section{DISCUSSION, CONCLUSION, and IMPLICATIONS}

In this study, a scale was developed with the aim of measuring third- and fourth-grade primary school students' attitudes towards story writing. A 30-item draft scale was developed based on the literature and implemented with participants. Following the implementation, validity and reliability were tested in order to determine the structure of the final scale, which was identified as comprising 20 items.

Construct and content validity were measured. To test construct validity firstly, EFA was conducted, then in order to confirm the two-factor construct obtained, CFA was conducted. There are 10 items in the first factor and 10 items in the second factor. Since the items in the first factor contain positive attitudes towards story writing, this factor is called "positive attitude". When the statements in the second factor are examined, it is seen that they reflect the negative expressions towards story writing. Therefore, it was decided to call this factor "negative attitude". Between them, the two factors explained $53.06 \%$ of total variance; the first factor explained $40.73 \%$, while the second factor explained $12.33 \%$. CFA revealed that the model is in harmony with its data. Based on the EFA and CFA analyses, it can be stated that the two-factor scale is valid. To achieve content validity, the relevant literature was reviewed, definitions of storytelling attitude were determined, and items were formed according to these definitions. Additionally, three experts in the field were consulted about the items.

To ensure reliability, $\alpha$ and TRR coefficients were calculated. According to this, the $\alpha$ of the overall scale was .92 , that of the first sub-factor was .90, and that of the second sub-factor was .89 . The results of the tests show that the scale is reliable.

The results showed that "Attitude Scale Toward Story Writing" has a valid and reliable structure. In this respect, it can be stated that the scale is suitable for use to measure third- and fourth-grade students' attitudes towards story writing. This scale contributed to filling the gap in the literature.

Turkish Teaching Curricula prepared in 2005 and 2015 include story writing starting in primary school. To ensure that this work is productive, it is important for the teacher to identify students' attitudes and work on them to encourage a positive attitude towards story writing. When the literature is examined it is seen that researches and scale development studies have been done to examine the relationship between writing attitude and writing success, developing a tool to determine the writing attitude for teachers, determining the writing attitudes of the 1-3. and 4-8. grades students, influence the writing behavior of creative writing activities, comparison of reading and writing attitudes (Clark \& Dugdale, 2009; Graham vd., 2007; Kear vd., 2000; Knudson, 1991; Knudson, 1992; Susar-Kırmız1, 2009; Temizkan \& Sallabaş, 2009). In Gallick-Jackson's (1997) study, an instrument was used to measure the students' writing attitude to identify their story writing attitude. However, students' attitudes towards story writing may differ from their attitudes towards writing. For instance, a student may not like writing about the topics they learn at school, but s/he may like story writing on a topic of his/her own choosing. The use of tools to measure writing attitudes in determining attitudes towards story writing can lead to misleading results. For this reason, it is considered that it is necessary to develop a measurement tool to determine the story writing attitude. Since students are familiar with story texts from early ages, and in primary school writing studies are usually focused on story texts, therefore, it is considered that measuring story writing through scales which are specifically designed with a focus on this subject may provide realistic results. Story writing attitudes of third and fourth grade primary school students will be determined by the Attitude Scale Towards Story Writing developed in this research. Future studies should be examined the story writing attitudes of different sample groups. Also, the researchers recommend that new scales should be developed in persuasive, informative, and other types of writing 
along with story writing. It is also recommended to analyze the validity and reliability English version of our attitude scale towards story writing developed in Turkish (Appendix 1).

\section{Acknowledgement}

This study was presented as oral presentation at 16th International Primary Teacher Education Symposium.

\section{REFERENCES}

Akyol, H. (2013). Türkçe ilkokuma yazma ögretimi (13th ed.). Ankara: Pegem Akademi Yayıncılık.

Ateş, S. (2011). Evaluation of fifth-grade Turkish course learning and teaching process in terms of comprehension instruction. (Unpublished doctoral dissertation). Gazi University Graduate School of Educational Sciences, Ankara, Turkey.

Bandura, A. (1995). Exercise of personal and collective efficacy in changing societs. In A. Bandura (Ed.), Selfefficacy in changing societies (pp. 1-45). Cambridge, England: Cambridge University Press.

Clark, C., \& Dugdale, G. (2009). Young people's writing: attitudes, behaviour and the role of technology. National Literacy Trust, 1-52.

Cohen, R.J., \& Swerdlik, M.E. (2015). Psychological Testing and Assessment. E. Tavşancıl (Translation Ed.). Ankara: Nobel Yayın.

Daly, J. (1985). Writing apprehension. In Mike Rose (Ed), When a writer can't write studies in writer's block and other composing process problems (pp. 43-82). New York: Guilford Press. Retrieved from https://www.researchgate.net/publication/306375000_Writing_Apprehension

DeVellis, R. F. (2014). Scale development. T. Totan (Translation). Ankara: Nobel Yayın.

Edwards, A. L. (1957). Techniques of attitude scale construction. New York: Appleton-Century-Crofts. INC.

Gallick-Jackson, S.A. (1997). Improving narrative writing skills, composition skills, and related attitudes among second grade students by integrating word processing, graphic organizers, and art into a process approach to writing. (Unpublished master's thesis). Nova Southeastern University, the USA. Retrieved from http://files.eric.ed.gov/fulltext/ED420064.pdf

Göçer, A. (2014a). The adaptation to Turkish of the writing attitude scale (WAS): The study of validity and reliability. Kastamonu Education Journal, 22(2), 515-524.

Göçer, A. (2014b). Yazma eğitimi. Ankara: Pegem Akademi.

Graham, S., Berninger, V., \& Fan, W. (2007). The structural relationship between writing attitude and writing achievement in first and third grade students. Contemporary Educational Psychology, 32, 516-536. Retrieved from http://www.sciencedirect.com/science/article/pii/S0361476X07000057

Gürefe, N., \& Kan, A. (2013). The study of validity and reliability of the attitude scale on the subject of geometric objects for the prospective teachers. Elementary Education Online, 12(2), 356-366. Retrieved from http://dergipark.ulakbim.gov.tr/ilkonline/article/view/5000037781/5000036639

Kan, A., \& Akbaş, A. (2005). Lise öğrencilerinin kimya dersine yönelik tutum ölçeği geliştirme çalışması. Mersin University Journal of the Faculty of Education, 1(2), 227-237. Retrieved from http://chemistrynetwork.pixel-online.org/data/SMO_db/doc/58_3.pdf

Kear, D. J., Coffman, G.A., McKenna, M. C., \& Ambrosio, A.L. (2000). Measuring attitude toward writing: A new tool for teachers. The Reading Teacher, 54(1), 10-23.

Kılıç-Çakmak, E., Çebi, A., \& Kan, A. (2014). Developing a "social presence scale" for e-learning environments. Educational Sciences: Theory \& Practice, 14(2), 755-768. DOI: 10.12738/estp.2014.2.1847

Kline, R. B. (2011). Principles and practice of structural equation modeling (3rd ed.). New York: Guilford Press.

Knudson, R. E. (1991). Development and use of a writing attitude survey in grades 4 to 8. Psychological Reports, 68, 807-816. Retrieved from http://journals.sagepub.com/doi/abs/10.2466/pr0.1991.68.3.807

Knudson, R. E. (1992). Development and application of a writing attitude survey for grades 1 to 3. Psychological Reports, 70, 711-720. Retrieved from http://journals.sagepub.com/doi/pdf/10.2466/pr0.1992.70.3.711

Krawczyk, J. (2005). Writing attitudes: determining the effect of a community of learners project on the attitudes of composition students. (Unpublished master's thesis). Faculty of the Graduate College of the Oklahoma $\begin{array}{lllll}\text { State University, } & \text { the } & \text { RSA. }\end{array}$ 
https://shareok.org/bitstream/handle/11244/9520/Krawczyk_okstate_0664M_1567.pdf?sequence=1\&isAl lowed=y

Nunnally, J. C., \& Bernstein, I. (1994). Psychometric theory (3rd ed.). New York: McGraw-Hill.

Turkey Republic Ministry of National Education Board of Education and Discipline. (2009). Elementary Turkish curriculum and guide (Grades 1st-5th). Ankara: Devlet Kitapları Müdürlüğü Basım Evi.

Turkey Republic Ministry of National Education Board of Education and Discipline. (2015). Turkish (Grades 1st8th) curriculum. Ankara: Devlet Kitapları Müdürlüğü Basım Evi.

Susar-Kırmızı, F. (2009). In Turkish courses the effect of creative writing efforts based on creative drama method on the writing attitude. Creative Drama Journal, 4(7), 51-67. Retrieved from http://yader.org/index.php/yader/article/viewFile/yader.2009.005/yader.2009.005

Tabachnick, B. G., \& Fidell, L. S. (1996). Using multivariate statistics. New York: HarperCollins.

Tavşancıl, E. (2010). Tutumların ölçülmesi ve SPSS ile veri analizi. Ankara: Nobel Yayın.

Temizkan, M., \& Sallabaş, M. E. (2009). Compare the attitudes of teacher candidates related to reading and writing activities. Electronic Journal of Social Sciences, 8(2), 155-176.

Tompkins, G. E. (1982). Seven reasons why children should write stories. Language Arts, 59(7), 718-721. Retrieved from https://www.jstor.org/stable/pdf/41405103.pdf

Tompkins, G. E. (2006). Literacy for the 21th century: A balanced approach. New Jersey: Pearson Education.

Turan-Oluk, N., Kan, A., \& Ekmekçi, G. (2016). The development of an attitude scale for concept mapping: the study for validity and reliability. KEFAD, 17(1), 95-110. Retrieved from http://kefad.ahievran.edu.tr/archieve/pdfler/Cilt17Sayi1/JKEF_17_1_2016_95-110.pdf

Williams, H. M. (2012). Third grade students' writing attitudes, self- efficacy beliefs, and achievement. (Unpublished master's thesis). Thesis submitted to the Faculty of the Graduate School of the University of Maryland, the USA. Retrieved from http://drum.lib.umd.edu/handle/1903/12981

Zumbrunn, S. (2010). Nurturing students' writing knowledge, self-regulation, attitudes, and self-efficacy: The effects of self-regulated strategy development. (Unpublished doctoral dissertation). University of Nebraska Lincoln, the USA. 


\section{APPENDIX 1. Attitude Scale Towards Story Writing in Turkish}

Sevgili Öğrenciler,

Aşağıda yer alan cümleler, tek başınıza hikâye yazma ile ilgili duygu ve düşüncelerinizi belirlemek amacıyla hazırlanmıştır. Her cümlenin karşısında, cümlede anlatılanlara ne düzeyde katıldığınızı belirlemeye yönelik beş ifade yer almaktadır. Sizden, cümlelere içten bir şekilde cevaplar vererek hikâye yazma ile ilgili kendinizi en iyi anlatan ifadeye işaret koymanız istenmektedir. Lütfen tüm cümleleri yanıtlayınız. Yanıtlarınız hiçbir şekilde puan olarak değerlendirilmeyecektir.

TEŞEKKÜRLER...

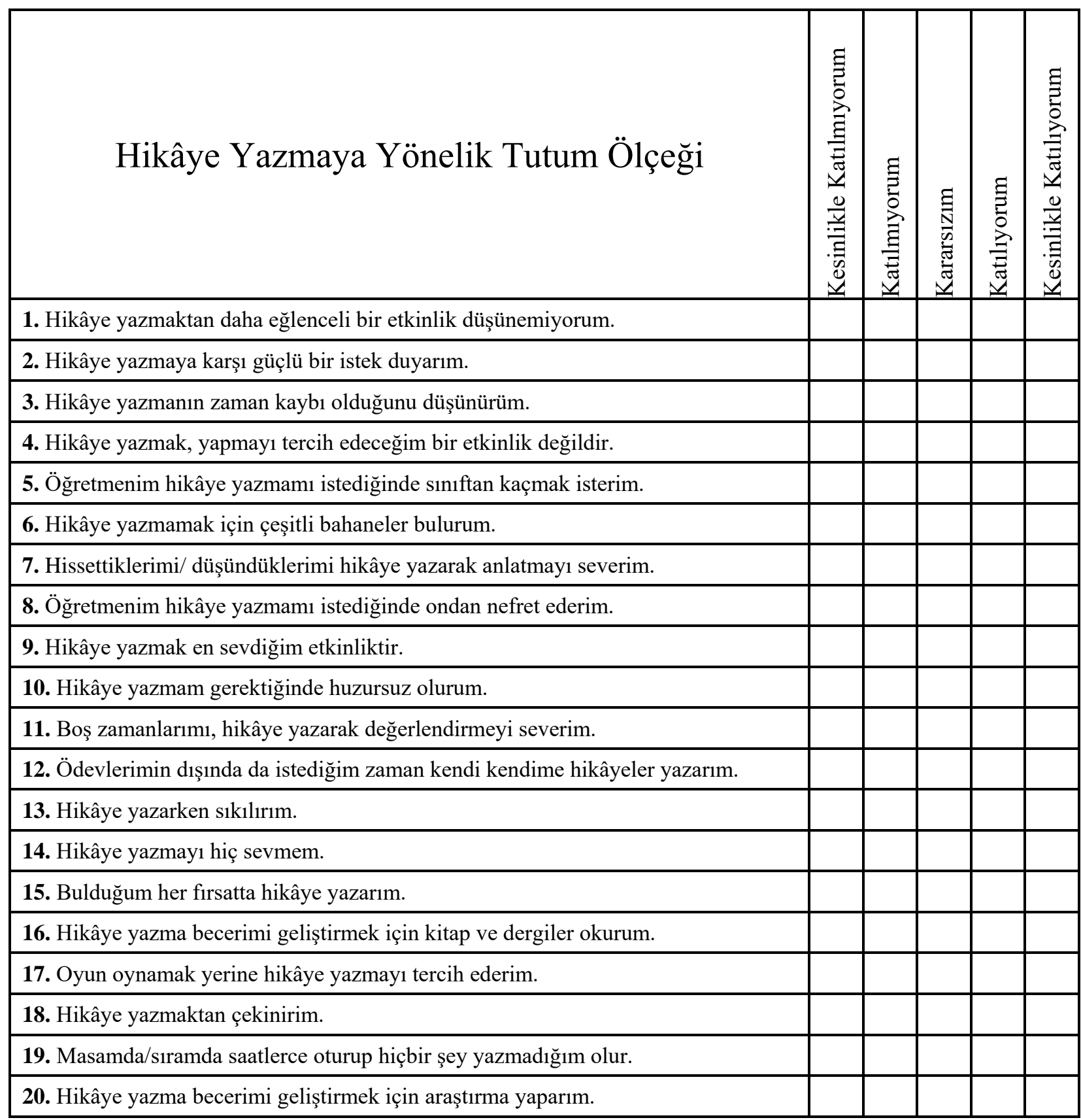




\section{TÜRKÇE GENIŞLETILMIŞ ÖZET}

Bireyler kendilerini ifade etmek, duygu ve düşüncelerini aktarmak gibi çeşitli sebeplerle yaşamları boyunca yazma becerisini kullanmaktadır. İletişim sürecinde oldukça önemli olan yazma becerisine karşı her bireyin ilgi, istek ve tutumları aynı değildir (Göçer, 2014). Öğrencilerin okul öncesi dönemlerden itibaren hikâye türü metinlerin yapılarına aşina olmaları (Ateş, 2011), Türkçe Öğretim Programında, ilkokuldan itibaren hikâye yazma çalışmalarına yer verilmesi sebebiyle bu çalışmaların daha verimli geçmesini ve öğrencilerin hikâye yazmaya yönelik olumsuz tutumları varsa bunları belirleyip olumlu tutum haline getirmeyi sağlamak için öğrencilerin hikâye yazmaya yönelik tutumları belirlenmelidir.

$\mathrm{Bu}$ araştırmada ilkokul üçüncü ve dördüncü sınıf öğrencilerinin hikâye yazmaya yönelik tutumlarının belirlenmesi için geliştirilen Likert tipi bir tutum ölçeğinin geçerlik ve güvenirlik çalışmasının yapılması amaçlanmıştır. Bu araştırmanın çalışma grubunu Zonguldak ili Ereğli ilçesinde yüksek, orta ve düşük sosyo-ekonomik düzeydeki (SED) öğrencilerin devam ettiği üç farklı ilkokulda üçüncü ve dördüncü sınıfta öğrenim gören toplam 354 öğrenci oluşturmaktadır.

Ölçek geliştirme sürecinin ilk aşamasında konu ilgili çalışmalar incelenmiş, literatürde konuya ilişkin ölçek bulunup bulunmadığı araştırılmıştır. Ardından ilkokul üçüncü ve dördüncü sınıf öğrencilerinin hikâye yazmaya ilişkin tutumlarını ölçmek amacıyla bilişsel, duyuşsal ve davranışsal boyutlar göz önüne alınarak 30 madde yazılmıştır. Maddelerin ve kullanılan dilin uygunluğuna ilişkin üç alan uzmanı, bir ölçme değerlendirme uzmanı ve bir dil uzmanından görüş alınmış ve taslak ölçek oluşturulmuştur. Faktör analizi öncesinde olumsuz maddelerin puanları ters çevrilerek puanlama yapılmıştır.

Verilerin toplanması aşamasında katılımcılara çalışmanın amacı açıklanarak çalışmaya katılmak isteyenler belirlenmiştir. Taslak ölçeğin cevaplanma süresi 20-25 dakikadır. Veri toplama süreci ise testtekrar-test ile birlikte yaklaşık bir ay sürmüştür.

Hikâye Yazmaya Yönelik Tutum Ölçeğinin güvenirlik ve geçerliğine kanıt oluşturmak amacı ile çeşitli analizler yapılmıştır. Güvenirliğe kanıtı arttırmak için test-tekrar test (TTT) güvenirliği hesaplanmıştır. TTT çalışması için her bir okuldan seçilen 12 öğrenci olmak üzere toplam 36 öğrenciden ayrıca veri toplanmıştır. Ölçeğin yapı geçerliğine kanıt oluşturmak için Açımlayıcı Faktör Analizi (AFA) ve Doğrulayıcı Faktör Analizi (DFA) yapılmıştır. Ölçeğin geliştirilmesinde iç tutarlılık için tutum ölçeğinin tümü ve onu oluşturan faktörlere ait Cronbach-Alfa değerleri hesaplanmıştır.

İlk AFA sonucunda ölçeğin maddelerinin beş faktör altında toplandığ 1 görülmüştür. Bu beş faktörün ölçeğe ilişkin açıkladığı varyans \% 56.51'dir. Fakat bazı faktörlere çok az sayıda maddenin yük verdiği, bazı maddelerin birden fazla faktöre yük verdiği ve bazı yük değerlerinin ise .30 'un altında olduğu görülmüştür ve bu maddeler ölçekten tek tek çıkarılarak her seferinde AFA tekrarlanmıştır. Yapılan analizler sonucunda KMO değeri .94 olarak hesaplanmıştır. Barlett testi de anlamlı bulunmuştur ( $\mathrm{x} 2=4817.85 ; \mathrm{p}=0.00)$. Uygun olmayan maddelerin ölçekten çıkarılmasının ardından geriye kalan 20 madde iki faktör altında toplanmıştır. Faktör yüklerini daha belirgin hale getirmek amacıyla varimax kullanılmıştır.

Ölçeğin ilk uygulanışından iki hafta sonra 36 öğrenciye tekrar uygulanması sonucu elde edilen veriler üzerinde ölçme sonuçlarına ilişkin TTT güvenirliği hesaplanmıştır. Ölçeğin tümüne ait TTT güvenirliği .82 , birinci alt faktöre ilişkin TTT güvenirliği .87, ikinci alt faktöre ilişkin TTT güvenirliği ise .83 olarak hesaplanmıştır. Buna göre, kişilerden elde edilen ölçek puanları geçen zamana karşı tutarlılık göstermektedir. 20 maddeye ait AFA değerleri incelendiğinde birinci boyut faktör yükünün .55 ile .80 arasında değişen 10 maddeden; ikinci boyut faktör yükünün ise .50 ile .76 arasında değişen 10 maddeden oluştuğu görülmektedir. Tüm faktörlerin toplam varyansın \%53,06'sını açıkladığı belirlenmiştir. Birinci 
faktör toplam varyansın \%40,73’ünü açılamakta olup "Olumlu Tutum” olarak, ikinci faktör toplam varyansın \%12,33'ünü açılamakta olup, "Olumsuz Tutum” olarak isimlendirilmiştir. Faktörler arasındaki korelasyonun .38 olduğu ve .05 düzeyinde anlamlı farklılığa sahip olduğu görülmektedir.

DFA'ya ait faktör dağılımları ve yük değerleri, maddeler ile ilişkili oldukları faktörler arasındaki yük değerlerinin 0.53 ile 0.83 arasında değişiklik göstermektedir. DFA sonuçlarına göre iki faktör arasındaki korelasyon değeri .64'tür ve anlamlıdır. Buna göre, ölçekte yer alan maddelerin yapıyı temsil ettiği, modelin AFA ile ortaya konan sonuçlarla uyum gösterdiği söylenebilir.

Ölçeğin güvenirliğini belirlemek üzere; ölçekte yer alan her bir madde için madde-toplam test puanları arasındaki korelasyonlar hesaplanmış, AFA neticesinde belirlenen ölçeğin her bir boyutuna ilişkin Cronbach Alpha güvenirlik katsayıları hesaplanmıştır. Ölçeğin tümüne ait $\alpha .92$; birinci alt faktöre ilişkin $\alpha .90$, ikinci alt faktöre ilişkin $\alpha .89$ olarak bulunmuştur. Bu verilere göre, ölçeğin oldukça yüksek güvenirlik değerlerine sahip olduğu görülmektedir.

Her bir faktörde yer alan maddelerin toplam test korelasyonlarına bakıldığında ise olumlu tutum faktöründe değerler $(\mathrm{r}=.56)$ ile $(\mathrm{r}=.76)$ arasında, olumsuz tutum faktöründe ise değerlerin $(\mathrm{r}=.49)$ ile $(\mathrm{r}=.76)$ arasında değiştiği görülmektedir. Bu ölçeğin madde toplam test korelasyonları incelendiğinde her bir maddesinin ( $r=.30)$ 'un üzerinde olduğu görülmektedir. Bu durum, ölçek maddelerinin ölçülmek istenen özelliği ölçme amacına hizmet ettiğine işaret etmektedir.

Özetle, ilkokul üçüncü ve dördüncü sınıf öğrencilerinin hikâye yazmaya yönelik tutumlarını ölçmeyi amaçlayan "Hikâye Yazmaya Yönelik Tutum Ölçeği”nin (EK 1) geçerli ve güvenilir bir yapıda olduğu ortaya konmuştur. 